\title{
A patient with Korsakoff syndrome of psychiatric and alcoholic etiology presenting as DSM-5 mild neurocognitive disorder [Corrigendum]
}

\author{
Nikolakaros G, Kurki T, Myllymäki A, Ilonen \\ T. Neuropsychiatr Dis Treat. 2019;15:1311-1320.
}

The author has advised that four errors have been detected in the reference list. Some of these issues were introduced throughout the production process of this paper. The issues are outlined as follows:

Reference 1: "Pietro SG, Serra A. Wernicke's encephalopathy: new clinical settings and recent advances in diagnosis and management. Lancet Neurol. 2007;6(5):442-455. doi:10.1016/S1474-4422(07)70104-7" should be replaced with "Sechi G, Serra A. Wernicke's encephalopathy: new clinical settings and recent advances in diagnosis and management. Lancet Neurol. 2007;6(5):442-455. doi:10.1016/ S1474-4422(07)70104-7'”.

Reference 19: "Ishibashi S. Reversible acute axonal polyneuropathy associated with Wernicke-Korsakoff syndrome: impaired physiological nerve conduction due to thiamine deficiency? J Neurol Neurosurg Psychiatry. 2003; 74(5):674-676. doi:10.1136/jnnp.74.5.674" should be replaced with "Ishibashi S, Yokota T, Shiojiri T, et al. Reversible acute axonal polyneuropathy associated with
Wernicke-Korsakoff syndrome: impaired physiological nerve conduction due to thiamine deficiency? J Neurol Neurosurg Psychiatry. 2003;74(5):674-676. doi:10.1136/jnnp.74.5.674”.

Reference 41: "Park SH, Kim M, Na DL, Jeon BS. Magnetic resonance reflects the pathological evolution of Wernicke encephalopathy. J Neuroimaging. 2001; 11(4):406-411." should be replaced with "Park SH, Kim M, Na DL, Jeon BS. Magnetic Resonance Reflects the Pathological Evolution of Wernicke Encephalopathy. J Neuroimaging. 2001;11(4):406-411. doi:10.1111/j.15526569.2001.tb00070.x".

Reference 64: "Palazon Cabanes B, Martinez Lerma EJ, Fuentes Fernandez I, Hernandez Clares R. Late presentation of wernicke's encephalopathy after gastrectomy in a patient with gastric adenocarcinoma: case report [article in Spanish]. Acta Neurol Colomb. 2015;31(4):412-416." should be replaced with "Palazón Cabanes B, Martínez Lerma EJ, Fuentes Fernández I, Hernández Clares R. Late presentation of wernicke's encephalopathy after gastrectomy in a patient with gastric adenocarcinoma: case report [article in Spanish]. Acta Neurológica Colomb. 2015;31(4):412-416. doi:10.22379/242240260".
Neuropsychiatric Disease and Treatment is an international, peerreviewed journal of clinical therapeutics and pharmacology focusing on concise rapid reporting of clinical or pre-clinical studies on a range of neuropsychiatric and neurological disorders. This journal is indexed on PubMed Central, the 'PsycINFO' database and CAS, and is the official journal of The International Neuropsychiatric Association (INA). The manuscript management system is completely online and includes a very quick and fair peer-review system, which is all easy to use. Visit http://www.dovepress.com/testimonials.php to read real quotes from published authors. 